\title{
Heritage for Development, Multiethnic Communities, and the Case of Butrint National Park on the Albanian-Greek Border
}

\author{
Dana Phelps
}

Stanford University

\begin{abstract}
The case study presented in this paper is an account of six months of ethnographic fieldwork that I conducted between 2010 and 2013 in the villages within the UNESCO World Heritage site of Butrint National Park, located on the Albanian-Greek border. My ethnography reveals the particularly complex tangle that exists between development and beritage projects in transitioning countries such as Albania, which is re-positioning its governance within a neoliberal framework. The research takes an anthropological approach to investigate how the "heritage for development" projects at Butrint National Park are affecting the local community and distressing local power relations and social inequalities, while at the same time are instilling a sense of place for many of these communities that have relocated or were forced from their homes during the post-communist period as a result of confusion over land ownership. This case study demonstrates that while sustainable heritage practices are often overpowered by neoliberal agendas, heritage repurposed towards development has real and powerful effects on the communities connected to the site. In this paper I argue that we need anthropologically informed studies that give due attention to the realities of the communities connected to the site in order to reveal how sustainable heritage policies that are not set up to protect the community can have detrimental effects on the locals, including reinforced structural inequality, marginalization of minorities, and divisions among communities.
\end{abstract}

Keywords: Cultural heritage, community development, post-socialism, European Union, community archaeology, the Balkans.

\section{Introduction}

When heritage is repurposed towards development it becomes inflated with concerns of institutionalization, social agency, popular sovereignty, and community participation. These issues become especially apparent in countries that are situated in a postsocialist political and social space, which includes much of Central and Eastern Europe (Berdahl 2010; Dimova 2009; Elyachar 2005). This paper takes as its primary case study Albania, a country that is not only in a state of economic and political development, but one which has been excluded from the European sphere (Pettifer \& Vickers 2009; Balibar 2004). The case study presents six months of ethnographic fieldwork that I conducted between 2010 and 2013 in the villages within the UNESCO World Heritage site of Butrint National Park, located on the Albanian-Greek border. My ethnography reveals the particularly complex tangle that exists between development and heritage projects in transitioning countries such as Albania, which is re-positioning its governance within a neoliberal framework (Pettifer \& Vickers 2009). The research takes an anthropological approach to investigate how the "heritage for development" 
projects at Butrint National Park are affecting the local community and distressing local power relations and social inequalities.

Thus, this paper is correspondingly about how the socio-economic rights of local communities in Albania are revealed (or suppressed) through policies that do not take into account their social agency, such as is the case with many sustainable development policies and practices. This failure to center communities within development projects is seen in many of the unsuccessful heritage tourism projects in Southeast Asia that devastate connected communities (Winter 2007; 2010); in the indigenous heritage protection projects that do not give full agency to the indigenous peoples (Herrera 2014); and in the community archaeology projects that do not fully understand and engage its local community and thus assume that the project has no effect on the people (Gould \& Burtenshaw 2014; Chirikure et al. 2010). Through an in-depth anthropological analysis of the local communities of Butrint National Park, I show that while sustainable heritage practices are often overpowered by neoliberal agendas, heritage repurposed towards development has real and powerful effects on the local.

Sustainable development is that which aims to create a balance between economic, social, and environmental goals (Kumi et al. 2014: 544). However, within the neoliberal framework, this balance is near impossible to realize. Neoliberalism undermines the ability for these goals to be achieved, especially in developing countries, because the interest of the market is promoted at the expense of social and environmental development concerns and does not take into account the local enmeshment of social institutions, power relations, and socio-political structures, thereby often yielding a universalist and non-context dependent implementation of neoliberal practices on the ground (Rajak 2011a). Still, I believe that sustainable development can be achieved within a neoliberal government, as long as the policy and practices established are reframed so to understand the local complexities and place social agency at the forefront of the policy and practice. Therefore this paper does not seek to critique neoliberalism so much as it questions how social agency can breathe under neoliberal policies.

In this paper I argue that 'bad' sustainable development policy is that which rests solely within the neoliberal context, and is structured in such a way that its focus is not actually on the citizen, but is rather on trade liberalization and has aims to subject society to capitalist market relations. 'Good' 'heritage for development' practices, I argue, require community-centered policies and profound engagement with all local citizens, including meaningful consultation and socio-political participation. We need anthropologically informed policy studies that give due attention to such issues in order to reveal how sustainable heritage policies that are not set up to protect the community can have detrimental effects on the locals, including reinforced structural inequality, marginalization of minorities, and divisions among communities.

This study comes at a critical moment. Sustainable heritage practices have become all the rage (Barthel-Bouchier 2013), and community archaeology projects are proliferating (Silverman 2011). However, as this paper hopes to demonstrate, we need reflect on these projects before pursing them further, giving them the anthropological critique that they need. We need to do this now before these seemingly harmless community archaeology and 'heritage for development' practices have lasting damaging effects on the local, and even on the site. 


\section{Part I. Sustainable development and heritage under a neoliberal apparatus}

Before attempting to understand the complexities between heritage-based development and the citizen in Albania, it is necessary to understand the exclusionary effects that the European Union (EU) has on policymaking and notions of citizenry in non-EU, postsocialist countries, or as Gerard Delanty (1995: 140) nominates them, the 'Anti-Europe'. The EU's adoption of a neoliberal agenda in the 1980s forced EU policymakers to envision and produce a new idea of citizenship for the EU (Hansen 2000: 141). While the 1970s EU community looked towards collective social needs as the basis of its citizenry, the 1980s shed this welfare statist agenda for a neoliberal one, which focused on a shared cultural heritage and value as the foundation of the EU citizen (Hansen 2000: 143). Its new foundation of a collective cultural and historical narrative, one which is Greco-Roman and Judeo-Christian, meant that the EU now had the justificatory power to exclude countries based off of heritage, culture, and religion (Shore \& Abélès 2004). European citizenship, therefore, as endowed through the EU, has come to serve as the reward for a neoliberal economy that fits within a particular ethno-culturalism (Balibar 2004). Therefore, it should come to no surprise that the excluded countries that are vying for EU acceptance are using their heritage as a means for defending their case for EU approval.

The sharp shift in economic policy from a social welfare state to a neoliberal free-market economy in many of these post-socialist countries 'shocked' the government and its citizens (Berdahl 2010; Elyachar 2005). One of the byproducts of this shock has been the marginalization of groups that cannot be situated within a particular socio-economic aesthetic that the new government is attempting to construct (Sigona \& Trehan 2010: 2). The sudden switch from an authoritarian economy to a laissez-faire capitalism had the unanticipated effect of pushing minority groups out of the labor market, essentially increasing marginalization and impoverishment in these countries. Indeed, social inequalities are extreme in Eastern Europe and its civil society is actually fixed within a global civil society that is dominated by neoliberal policies (Dimova 2009: 4).

Neoliberalism as both an economic and political discourse have taken over the development sphere in many of these countries (Sigona \& Trehan 2010). Proponents of neoliberalism insist that market-based strategies promote efficiency, competition, and stabilization of the economy (Harvey 2007; Kingfisher \& Maskovsky 2008). Yet empirical studies on neoliberalism and its market strategies challenge these assumptions. First of all, policy that is rooted in neoliberal agendas focuses on large-scale, economic growth, a concept that runs counter to sustainable development, which is intended to keep development on a level that is supportable by locals and the nation at large (Gow 2002). For example, while mass tourism could bring in immediate economic growth, the effects of such tourism on the cultural and natural landscapes and its people could be so detrimental that in the long term, the site of tourism would no longer be a desirable attraction for visitors and the locals could be in a state of further impoverishment (Barthel-Bouchier 2013; Comer 2012; Chirikure et al. 2010; Meskell 2010). This neoliberal logic has failed to address the needs of the poor, and the rewards are often distributed to those in power or to only a select group of the poor, meaning that this free-market rewards system only reinforces the inequalities present, making the strong "stronger" and the weak "weaker" (Kumi et al. 2013). 
Thus, heritage repurposed for development under neoliberal principles is heritage that is entering a slippery slope. This new trend to position heritage for development by international organizations, NGOs, national governments, and even local organizations, is criticized by many scholars who point out the emptiness of these policies when servicing a neoliberal government (Coombe \& Baird 2016; Barthel-Bouchier 2013). Yet, the criticism should go farther than pointing out the hollow and self-serving nature of these policies and should scrutinize the often damaging effects that these policies can have on the very community that the policy is theoretically intended to serve. This only reiterates the fact that we are in need of anthropologically informed studies that unveil the policy effects at the most local of levels.

In rhetoric, these policies are put in place to mobilize heritage as a resource for the purpose of alleviating poverty, sustaining livelihoods, bolstering social cohesion, and reinventing communities through infrastructure development and new forms of cultural enterprises (Lafrenz Samuels 2010). Unfortunately, many of these policies serve an ulterior motive and are framed to benefit a nation's elite rather than the local community that is played by the policy (Rajak 2011a). The effects of these policies do trickle down to the local levels, and since these effects are uncontained or unanticipated, they can have real and damaging effects on the communities that have now become victim to what was seemingly mere neoliberal development speech (Gupta 2012; Rajak 2011a; Rajak 2011b).

Yet, it is not just the policy that is giving way to such injustices. The sustainable development programs that are implemented on the ground are usually just as superficial as the policies are themselves. Recent critique has scrutinized the policies and practices that label themselves as "bottom-up," "participatory," or "community-driven," arguing that these policies hide external interests and agendas through language that appears humanitarian and to serve the local (Mosse 2004: 643). Furthermore, there is a tendency to homogenize the local, whether to serve external interests or because the plurality of the local is overlooked. Local communities are often geographically dispersed and socio-economically fractured (Li 2007: 245). As such, locals have different needs and perceptions, and are likely organized in systems of socio-economic inequalities and uneven power hierarchies. Ironically, these social inequalities cannot be solved through the very neoliberal apparatus that created them in the first place (Kumi et al. 2013: 549).

\section{PART II. The Case Study: Butrint National Park, southern Albania Butrint National Park: An overview of its resources and people}

Butrint National Park (BNP) is both an archaeological park and nature reserve. As one of Albania's two UNESCO World Heritage sites, Butrint has long been important for defining the cultural heritage of the Albanian people. Its exceptionality has been recognized internationally since its first excavations under the Italians in the 1920s and since has been the cultural pride of the Albanian people. Its international importance has brought in tourism, mainly by way of Greece, with the Greek island of Corfu located just ten kilometres from the site. 


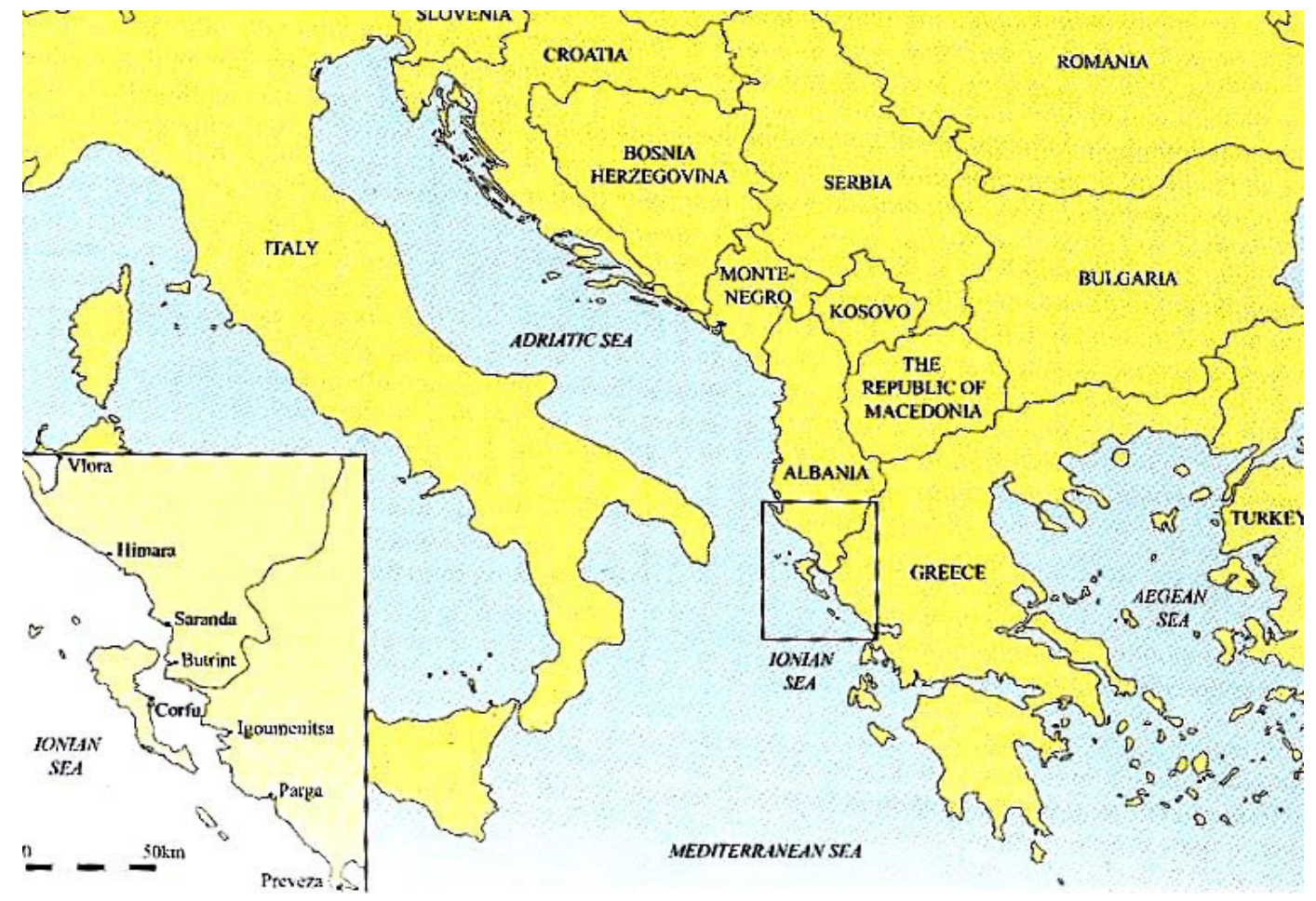

Figure 1. Map positioning Albania and Butrint in the Ionian Sea (photograph courtesy of the Butrint Foundation).

While the cultural aspects of Butrint are significant for the Albanian 'community' at the national level, the natural aspects are primarily important for supporting the local community. The tension between national and local significance reveals itself through the management of the park, which prioritizes the national needs above the local. BNP incorporates and is surrounded by low-income fishing and farming villages (Butrint Foundation 2006). The Commune of Xarrë is situated on the Vrinë Plain, across the Vivari Channel and opposite the archaeological site. The commune encompasses the villages of Shëndëlli, Vrinë, Xarrë, and Mursi, which are the primary villages represented in this study. Both Shëndëlli and Vrinë are near the entrance to the gated site, and all four villages lie on BNP confines.

After the fall of communism, Albania went through a period of mass migration as Albanians fled poverty and decades of oppression to seek better lives in Italy, Greece, and other nearby countries (Hall 1999: 169). In 1997, nation-wide pyramid schemes failed, further devastating an already impoverished population and throwing Albania into a period of civil unrest and yet again encouraging mass migration. During these two periods, communities at large from the north of Albania moved into the area that is now BNP and established the Catholic village of Shëndëlli. Vrinë, the smallest village, was also established during this period, although the villagers are from the south of Albania and the north of Greece. Xarrë and Mursi, unlike the other villages, are communities that have been established on the Vrinë Plain since the beginning of the twentieth century. 
The massive migration that occurred during the 1990s greatly affected village life. The high level of emigration resulted in a general loss of human resources in the area, which limited the development of new services and economic activities in the villages (CISP 2004). Other factors leading to low economic growth are the deprived education and health systems, and lack of infrastructure. In Shëndëlli, for example, poverty levels are some of the highest in Albania, with an average family income of approximately 200 USD a month (Butrint Foundation 2006; ASPBM Sept 2010).

In 1992 Butrint was added to the UNESCO World Heritage list for criterion iii,

\section{"to bear a unique or at least exceptional testimony to a cultural tradition or to a civili- zation which is living or which has disappeared" (UNESCO 2004).}

Butrint was established as a national park in 2000 in order to manage and protect the site's cultural and natural resources, as well as to better present the site to the public (Butrint Foundation 2005). In 1999, in preparation for the foundation of the BNP, a management board for the park consisting of government elites was set up that focused on protecting Butrint's cultural resources (ASPBM Sept 2010). This could be seen as the founding moment when an elite-based structure was created that was given control over the local heritage.

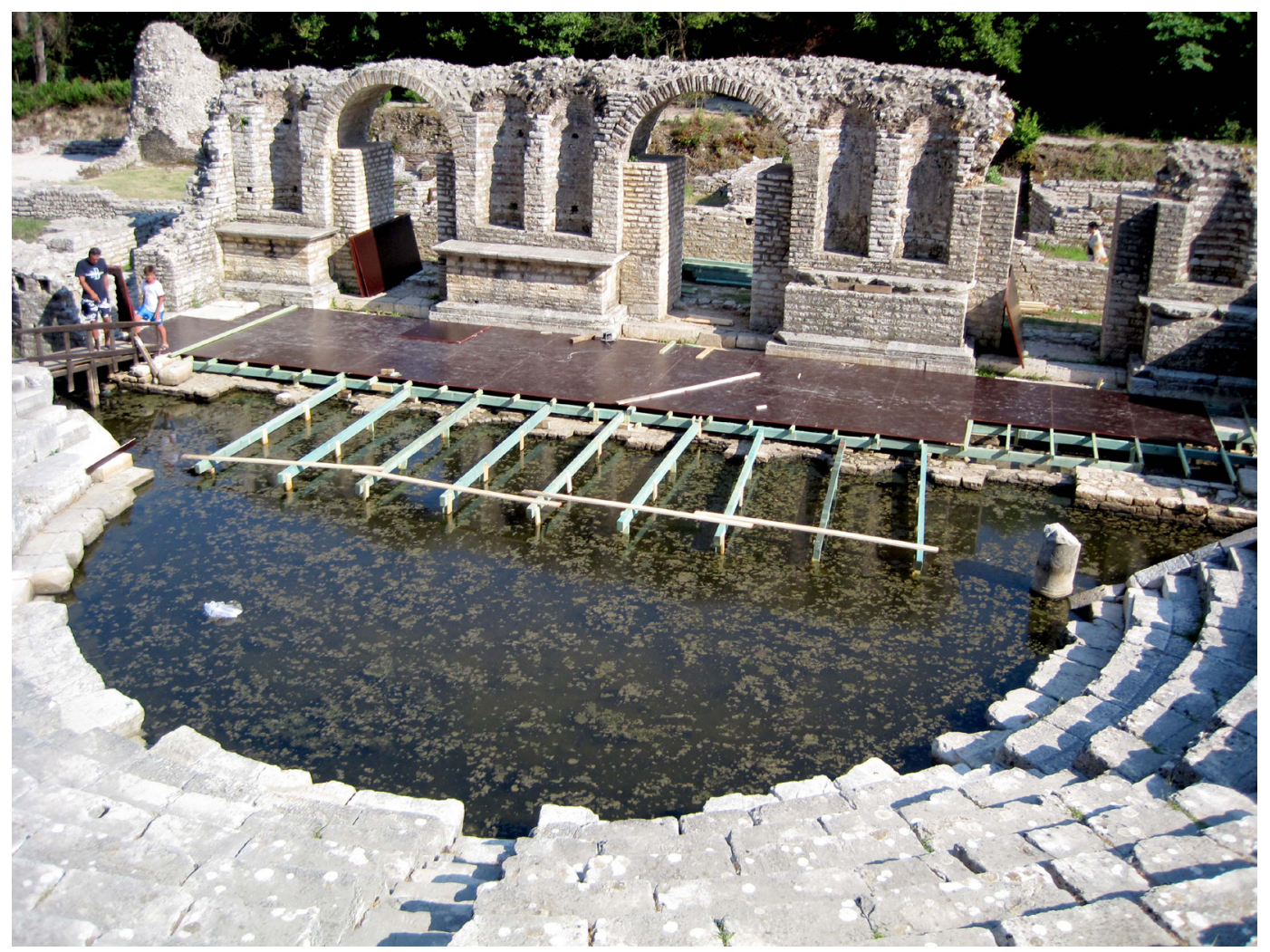

Figure 2. Roman Theater at Butrint (photograph by D. Phelps). 


\section{Community Development Projects}

It was not until after Butrint was established as a national park in 2000 that community development was recognized for its potential to support the sustainable management of the site. The introduction of community engagement initiatives marked a huge development for the site. Major projects set up by NGOs, foundations, and US governmental organizations include an on-site shop run by community members where locals can sell handmade products; local school visits to the site as part of school curriculum; environmental awareness activities, such as the planting of trees and learning about sustainable agricultural practices; the introduction of hiking trails into the villages to encourage tourists to Butrint to visit the local community; and training programs with the aim to hire workmen for excavations and conservation efforts.

In an interview with a former Butrint Foundation director, Daniel Renton, I learned that their specific projects began so that BNP could become financially independent. There was an understanding in 2006 that the Butrint Foundation may not exist in the future and that sustainable management approaches were necessary for ensuring that BNP would be able to care for the site without the financial support of the Butrint Foundation.

The ethnography I conducted first in 2010 was intended to understand the complexities of heritage-based community development work at BNP, identify any underlying problems, and grasp the communities' investment in the site. However, as I became more engaged with the communities over the next few years, the ethnography also became about getting at the heart of local opinions, identities, and views regarding how BNP has constructed and managed their local heritage. The results of both the community and management interviews that I conducted provided a wealth of information that most likely would have gone unnoticed without a deep anthropological research approach. The ethnography revealed that many of these projects were not structured to consider the plurality of the local identities, and that they were unintentionally marginalizing certain locals as well as reinforcing social inequalities. At the same time, the projects had benefited the communities through strengthening site awareness and appreciation, instilling a sense of place through the ancient ruins that adorn the landscape. Through this awareness, the communities had revealed a desire to mobilize themselves for self-governance of sustainable development projects.

Perhaps the most obvious complication of the projects is that they did not recognize the plurality of identities of the local communities. The projects had been set up in a way that would enable sustainable development of both the archaeological site and 'the Community'. However, within BNP, there is more than one community. The village of Xarrë is inhabited by a Greek minority that is mostly Orthodox. Vrinë is largely populated by a contested minority group, the Çam Albanians, who are mostly Muslim and face heavy discrimination in Greece. These two minority groups co-habit the area peacefully, although they have different religions and have historically been in violent conflict with one another. The villagers of Shëndëlli are Catholic and come from the Mirëdita region in the north of Albania. This community is considered a "displaced" community that migrated to the area at the fall of communism, when citizens were now free to move within the country. The migration was largely due to a desire to escape the blood feuds pervasive in the Mirëdita region, as well as to seek 
socio-economic improvement in one of Albania's most agriculturally rich areas. Each village and its diverse ethnic groups share different opinions about Butrint, its role in their lives, and their needs and desires from BNP. However, the projects seemed to assume a homogenous local, and thus were unable to respond to distinctive conflicts, identities, and needs.

Secondly, the marginalization of certain community groups became apparent through the ethnography. While some projects made a strong attempt to include women in their various activities, including the running of the handicraft workshop and the employment of workwomen on the site, the minority groups of Xarrë and Vrinë were not included. Additionally, several other villages are positioned within BNP, one of which is comprised largely of an Aromanian population, a Latin-speaking minority people native to the southern Balkans. Through interviews with the mayors of these other villages, I discovered that these villages have long been segregated from park activities. The villagers are aware of this separatism and have developed either resentment or indifference towards the park management and the Albanian government. If this marginalization had been recognized at the onset, the projects could have been designed to work towards the de-marginalization of these groups. While unintentional, through exclusion of these marginalized groups, the community development projects amplified this marginalization within BNP.

The third problem that the ethnography exposed was the socio-economic inequalities of these villages. For example, Xarrë profits more than the other villages do because, due to their Greek descent, many villagers move to Greece to make money, which they then send back to their families in Xarrë in the form of remittances. Villagers also return to Xarrë, often due to discrimination in Greece, to invest in a small business or build new homes for their families. Socially, Xarrë and Mursi are the most stable within the Commune since the villages have existed since before the communist period and are therefore well-established villages. Shëndëlli and Vrinë are both very poor villages, and rely on the fishing and farming industries for their welfare. Socially, Shëndëlli is not well integrated into the Commune, since they are a displaced people of the north of Albania. In particular, the ethnography demonstrated that Shëndëlli was victim to dis-

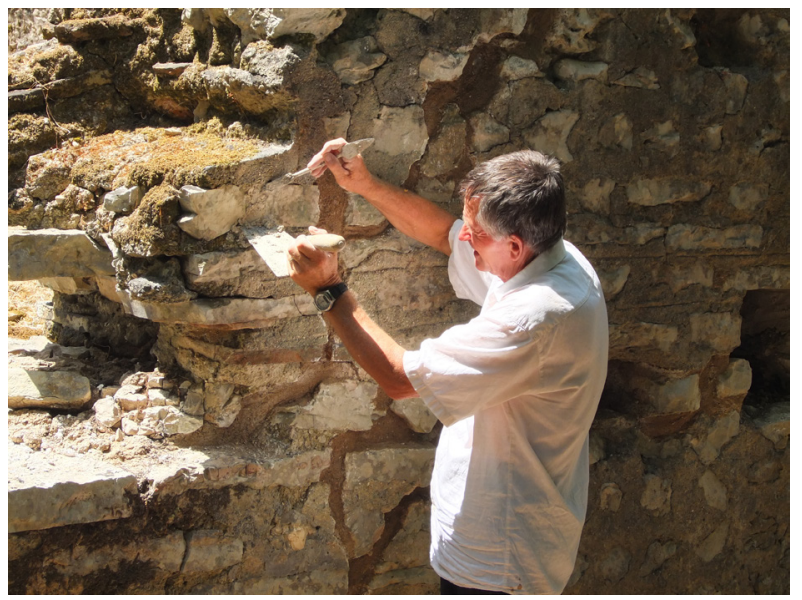

Figure 3. Shëndëlli workman repairing a Venetian wall at Butrint (photograph by D. Phelps). crimination. Interviews with villagers other than from Shëndëlli frequently brought forth discriminatory remarks against the villagers of Shëndëlli.

Aware of Shëndëlli's low socioeconomic status within the communities, the projects sought to support Shëndëlli by focusing their support on this one village. The family that runs the community shop at Butrint is from Shëndëlli and the vast majority of workmen and women on the site are from Shëndëlli as well. How- 
ever, this favoritism of Shëndëlli was at the expense of the villagers of Vrinë, Xarrë, and Mursi, which were not included to a similar degree. Evidently, interviews with villagers of Shëndëlli showed that many of these people were making a profit from the site. However, this was not the case for the other villages, where more villagers declared they were not making a profit. Many of the villagers of Vrinë expressed anger that they were not seeing a profit, noting that only a select group of people were profiting economically, and that these people came from Shëndëlli. One villager from Vrinë asked me in an interview, "What good has Butrint ever done for me? All I see are some families making money from Butrint. But no one cares about the rest of us." In some cases, there was clear resentment towards site management for not engaging the community more and helping them to profit economically. Another villager from Vrinë told me at the interview's onset, "If you are working with the site, I don't want to speak to you." In fact, many villagers of Vrinë did refuse to speak with me, angry that their voices were not being heard. The villagers of Xarrë and Mursi did not express this same anger, perhaps because they have other sources of economic rewards, or perhaps since their sense of place has been established in Butrint since long before communism took hold.

Interviews with park management showed an awareness of the selectivity in those that were profiting, but that the resentment that had been cultivated had gone unnoticed. While inadvertent, the projects had provoked conflict and negative attitudes through favoritism of Shëndëlli. Beyond resentment, the favoritism of the projects was reinforcing the socio-economic inequalities that already existed among the villages. While Shëndëlli was profiting, Vrinë was not.

While practices claim that they are engaging the local communities, it is typically the case that the engagement is limited to a select group of people or that the consultation itself is not very profound (Harrison 2012; Weiss 2014). On the ground, deep engagement with all social actors in play is necessary for understanding the plurality of a community, the local politics at play, existing power relations, and socio-cultural dispositions through which suprastructures are translated (Mosse 2004; Weiss 2014). It is also important for understanding where the socio-economic hierarchies and divides are currently active. It could also reveal conflicts that are emerging between groups as well as help practitioners to fully acknowledge all the marginalized groups that exist.

Furthermore, heritage and development practitioners have the ethical responsibility to deeply evaluate their policies at the local, national, and international levels. Understanding how and why these policies were written is equally as vital as engaging with the locals to understand the tangible effects that these policies may have on their way of life. In other words, examining heritage policy and practice requires a genuine

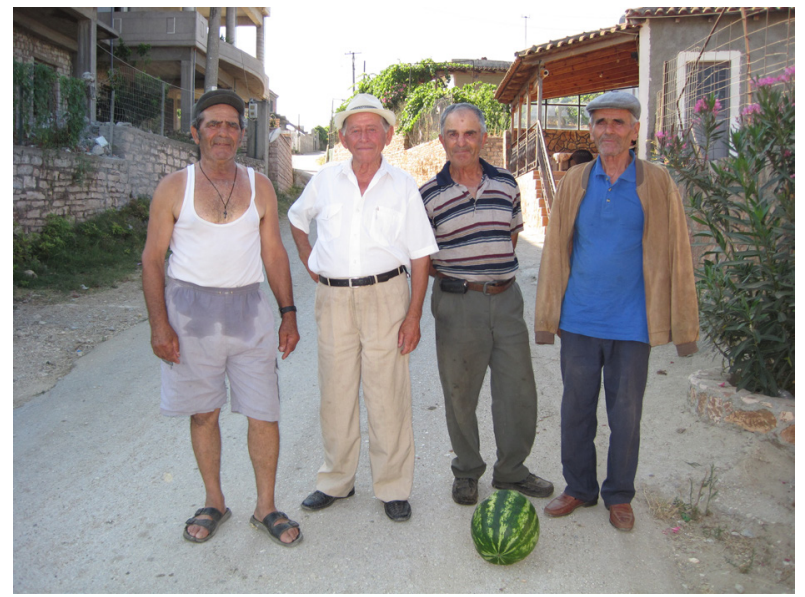

Figure 4. Greek minority locals from Xarrë, Butrint National Park (photograph by D. Phelps). 
ethnography, rather than a 'quick and dirty' evaluation that is likely to overlook the realities of such a complex entanglement of actors, values, and interests.

Having taken a Western approach to mobilizing local communities while lacking the deep knowledge of the very people that were likely to be affected by these policies and practices uncovered a recipe for calamity at BNP. The results of these projects demonstrate that community development initiatives that lack an anthropological understanding of the community as well as fully inclusive community engagement practices are likely to result in devastating socio-economic consequences for the community that that the policy and practice was intended to serve (Harrison 2012; Weiss 2014).

While I have cited thus far the reasons for why I believe these community development projects have not been a total success, I have yet to detail the positive effects that the project has had on the community. For the displaced people of Shëndëlli, Butrint and the community development projects have brought real meaning to their lives. Unable to travel within the country under the communist rule, quickly migrating to Butrint meant an abrupt rootlessness for them. Bringing with them a different culture, dialect, and way of life, they were soon to find themselves with the challenge of having to both integrate into society and to maintain their cultural values. One of the villagers of Shëndëlli said he feels that the people of this village are fortunate because they come from the north and maintain their cultural traditions while learning the new traditions of the surrounding villages. He added "I like the cultural exchange and feel that it has had a positive effect on my family and community."

A particularly interesting finding of the ethnography was that the people of Shëndëlli, above Vrinë and Xarrë, felt the strongest personal and social attachment to the site. Those outside of Shëndëlli discriminate against them, calling them "shepherds from the north", as I frequently heard, or simply were dismissive of their needs and opinions, assuming that they had none since they did not care about their new environs. Yet the ethnography shows that displaced peoples may actually feel a stronger attachment to their new land than those who have been rooted in that place (Pedersen 2009). "The migration to Butrint meant hope for a better life", said a villager from Shëndëlli. While they are still living in extreme poverty, they are no longer living under the rule of an oppressive and xenophobic regime. Thus, moving to Butrint after communism meant that these villagers associated Butrint with a less oppressive, more promising lifestyle.

It was clear through the interviews that the villagers of Shëndëlli and Xarrë have a great appreciation for Butrint and understand its importance as an historical site. Many villagers recounted how proud they are of Butrint and how they feel special to live so close to the site. One of the workmen from Shëndëlli recounted that Butrint has been "like a mother" to him. Another workwoman said that not only does she "love and care about Butrint, but everyone cares." Many workmen explained that the community's care for and historical knowledge of Butrint has grown since they have been working with the site. One explained that those that do not work directly with the site are interested in hearing about Butrint: "I bring stories home to my family and other community members, and even share them with tourists". 
Therefore, given the positive reaction of some of the locals towards Butrint as a place of appreciation, I believe that had a deep anthropological study of the communities been conducted, many of these socio-economic problems I noted would have been recognized and the projects could have been designed to rally this positivity while working toward overcoming the inequalities present in the communities. Instead, these projects were designed with a Western atti-

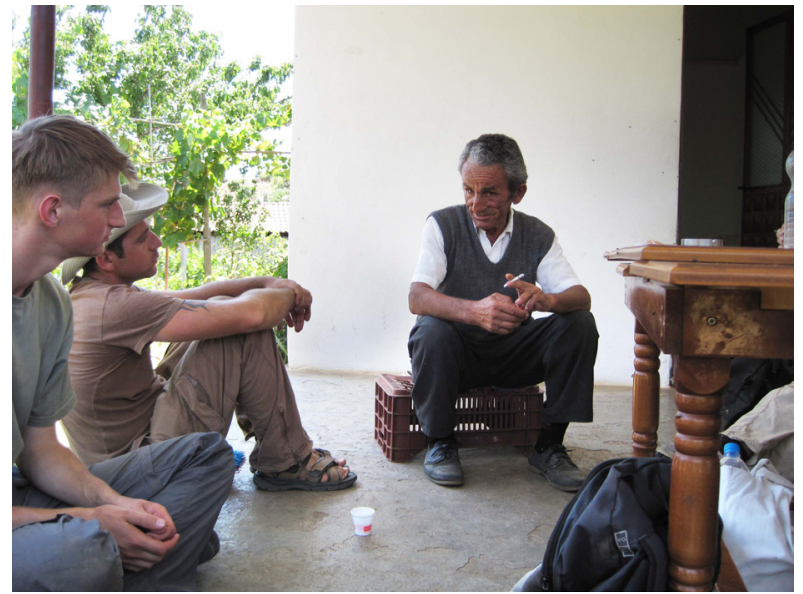

Figure 5. Interview with workman from Shendelli (photograph by D. Phelps). tude to mobilize communities for the sake of the heritage, thereby not giving the time to a deep anthropological analysis of the communities and their social agents, resulting in a streamlined project that was unable to deliver to its complex audience.

\section{Governance}

Governance of BNP is coming from two primary directions. Firstly, BNP is governed at the state level through policymaking and funding. The Butrint Foundation has been indirectly governing the site as a major donor through generous funding from the Packard Humanities Institute, as well as through private funding through Lords Sainsbury and Rothschild of the United Kingdom. The Butrint Foundation has people on the ground working to see their conservation and development projects through. The interviews with upper level management, including the BNP director at the time, and major players within the Butrint Foundation, demonstrated how unaligned agendas squandered projects at the local level.

As a country seeking EU integration, "economic growth is the government's first priority," said Richard Hodges, the Butrint Foundation's Scientific Director, in one of our many interviews in 2010 (Hodges 2010, pers. comm). The Albanian government sees heritage as one pathway to EU acceptance, however has yet to understand how heritage should be managed in a sustainable way. The neoliberal agenda of the Albanian government is therefore running counter to the sustainable development projects that the Butrint Foundation and other agencies are trying to implement. For example, while BNP confirms through its management plan that sustainable development is an important policy, the government supported the construction of a road through the BNP that was wide enough to support tour busses. The Butrint Foundation was adamantly against the building of the road, as it not only destroyed natural and archaeological resources, it was conducive for mass tourism.

One of the major difficulties that the Butrint Foundation has had with its community development projects is in making the Albanian government understand the importance of community development's role in the archaeological site's sustainability. As Hodges explained to me in an interview, "cultural heritage management is a new concept in 
Albania and the country has yet to adopt these new management strategies" (Hodges 2010, pers. comm). Without a system that is set up to support duelling agendas, heritage and community development projects (and other endeavors) will likely not return their intended effects.

Hodges believes that a major problem with the community development project today stems from a failure to put community members on the BNP's Management Board when BNP was formed in 2000. He revealed that neither the Butrint Foundation nor UNESCO truly understood the politics of Albania at the time. In hindsight, he believes the Butrint Foundation should have pushed harder for community representation. As a result, the board of directors is 'Tirana-centric' and therefore most of the money generated by BNP returns to the capital city of Albania, Tirana, rather than to the site or connected community (Hodges 2010, pers. comm).

Hodges (2010) noted in another interview that communist knowledge structures are still deeply imbedded in the way the site is managed (pers. comm). Butrint is now only used for political purposes and there remains little to no commitment to the site's stakeholders. Political corruption is thus an additional hindrance to the growth of community development at Butrint. The management approach at BNP is top-down and is therefore inconsiderate of the local economy. Political scandal and poor organization are resulting in a lack of funds and a disinterest in supporting community development and assisting the local economy, begging the question of what can be done to support a local community that is so invested in the wellbeing of BNP.

\section{Participation and Local Elitism}

From the interviews I held with local experts, it is clear that BNP management considers the 'local' to be the local elite. The management found that it was enough to speak with the mayors of the villages and other key community members, rather than gathering information from those that work the land. The mayor is a political figure and does not speak for all the needs and opinions of the village. Therefore, the community development projects were designed without true local-level consultation and were initiated with the power in the hands of the local elite from the onset. Without the most local-level and inclusive consultation and participation, the voices and needs of all the social agents at play will not be heard (Harrison 2012; Mosse 2004).

From the results of the ethnography, I saw community management and participatory programs as a real way to harness some of the positivity that the community development projects had produced within the community. Following the initial ethnographic research, I returned to Butrint in November 2010 to gather information for the feasibility of setting up a local stakeholder committee, which would have a key role in BNP governance.

I held several meetings with BNP management and potential committee representatives. Unlike the previous ethnography, which focused solely on the Commune of Xarrë, these meetings included the mayors from the Communes of Ksamil and Aliko, whose villages also lie within BNP confines. Additionally I interviewed several locals from each village to ensure that the voices of the non-elite were heard. Many of these interviews were conducted with those families with various connections to Butrint, such as the women and men that aid in excavations or the family that runs the handi- 
craft shop. Interviews were also conducted with community members that may have had no direct connection to the archaeological site. Although interviewing a sample of community members certainly has its limitations, especially given the lack of women in public locations in many of these villages, it also proved very useful for garnering opinions of those that are not involved directly with the site. However, the local community is multiple: there are numerous religions, cultures, dialects, occupations, histories, and diverse experiences of the past that have shaped each person's relationship with Butrint, the heritage, and the land. Interviewing numerous people from the villages allowed many of these identities and voices to come forth, however, more time would be needed to fully take in the complexity of the local community and its relationship to Butrint. What can be certain from the interviews, however, is that each community member I interviewed felt strongly about the possibility of integrating better with BNP and its management.

The then BNP director, Rajmond Kola, made it clear that he firmly believes in community development endeavors and is therefore strongly supportive of the idea of a local stakeholder committee that would surge dialogue between the community and BNP. The local elite, particularly the mayors of the villages and the area representative for USAID, explained that the communities demonstrate interest in the protection of BNP and that the community members understand its centrality to their livelihood. Moreover, they attested that the community members are not satisfied as being limited as members within BNP. They believe these limitations will increase the need for communication with BNP in the future.

The Heads of Villages and the selection of non-elite villagers interviewed believe that the villages are interested in more communication with BNP and that they will be able to organize meetings among themselves. In a focus group with potential representatives from the Commune of Xarrë, which included farmers, fishermen, breeders, and influential and non-elite members of the community, it was ascertained that the villagers of this commune are extremely interested in collaborating with BNP. The Head of Village of Xarrë helped organize this meeting and there was an impeccable turnout, further validating the community's capability and willingness to mobilize itself, and confirming its interest in the committee.

At present, BNP governance is working to make this local stakeholder committee a reality. While true governance through community (Rose 2004) has not yet been achieved, I believe that this case study demonstrates the possibility for change that will take communication more seriously so that stakeholder agendas are aligned. It additionally demonstrates that local communities can be heard and their socio-economic rights can be established, even in situations where it first seems hopeless, as it did for much of BNP governance at Butrint.

\section{Concluding Remarks}

The Butrint Foundation took the first step in community development efforts at Butrint. It developed a series of projects that have begun to connect the community to the site. It successfully established an awareness of and pride for the site, thereby creating heritage out of ancient ruins. This sense of heritage for the community was needed to ensure Butrint's protection and BNP's sustainability. However, a lack of a 
genuine anthropological approach prevented an understanding of the realities of the communities' needs, power structures, and existing socio-economic inequalities. Lacking this understanding, many of the projects only helped a select few while marginalizing the remainder, reinforcing the inequalities among the villages, and creating anger and resentment towards site management and towards those that are profiting.

Furthermore, political corruption and neoliberal policies and agendas suffocate these projects. The Butrint Foundation was unable at the time to negotiate a place for themselves in the fabric of the community. Because of this, the Foundation was forced to take over heritage production, thereby drastically challenging and even reinforcing power relations in the villages. Moreover, activities that had been initiated by the Foundation and other foreign investors to help the community were not carried through or maintained by site management. The unaligned agendas of the government and Butrint Foundation resulted in miscommunication and the Albanian government's disregard for the sustainability process that the Butrint Foundation had been fighting for. This was a clear example of how neoliberal agendas take precedence over and destroy sustainable development projects.

Finally, the community had never been considered in BNP management and there appeared to be little to no desire to economically support the local community as an important aspect of the national park. I see the local stakeholder committee as one step forward in securing local agency through participation. The existence of the committee would ensure that the communities are vital actors of BNP and that they are free agents with rights to participate politically, socially, and economically.

Sustainable community development projects are a complex web of obstacles. Designing a program that does not understand this complexity results in a failed project and an unintended effect of introducing or flaring socio-economic issues that may have been simmering. Beyond implementation of such projects, attempting to situate them in locations where neoliberal agendas override local concerns produces a monster of its own.

As seen through the Butrint case study, 'heritage for development' holds the potential for real positive change. The question now remains how to create good sustainable policies and practices that work within these existing elite-based governance structures. Sustainable development, in rhetoric alone, has the poor's best interest at heart. Given this mandate, I believe that 'good' sustainable development policy and practice is achievable; however, it requires a social agent-focused approach that does not give priority to economic growth with the assumption that the benefits will be distributed to the poor later. Rather, a good sustainable development policy will understand the complexity of the local community and consider how histories shape their present socio-economic conditions and identities. It will include all actors at play, from the poor to the elite, thereby placing greater emphasis on facilitating social rights such as political and social participation and creating opportunities for all social agents to contribute to a growing local economy. Therefore, we should not only be ensuring agency to the poor, but should be examining a new role for the elite and other actors so that uneven power relations are not unbalancing these policies and practices.

In insisting on the rights of all social agents to social and economic justices, cultural expression, and civic engagement, opportunities need to be created to which all social agents have 
access; cultural enterprises need to be set up in a way which has the potential to benefit every social agent; and every social agent needs to be made aware of his or her right to participate (Gow 2002). Only through full inclusion of all social agents can such policies and practices survive under a neoliberal regime. My suggestion therefore is for a community-centered heritage program that first involves a genuine anthropological analysis of the communities at stake; brings in true local-level stakeholder engagement and consultation; and then repositions governance so that it is also in the hands of the community. The community and all social agents must be at the heart of governance for local heritage projects to survive.

\section{Acknowledgements}

I am forever grateful to Richard Hodges for the incredible amount of time he has given to the support of my research. I am thankful to Valerie Higgins for inviting me to present a shortened version of this paper at the European Association of Archaeologists' 2014 Annual Conference in Istanbul. Special appreciation is also given to Gertjan Plets for his in-depth commentary, causing me to re-reflect on an ethnography that has taken years of data collecting and analysis to finally put to paper.

\section{References}

ASPBM, 2010. Integrated Coastal Zone Management and Clean-Up Project: Butrint Management Plan. Accessed 30 March 2015.

http://www.aspbm.org/uploads/Butrint-MP_final_revised_version_eng_September_2010.pdf._

Balibar, E., 2004. We, the People of Europe? Reflections on Transnational Citizenship. Princeton and Oxford: Princeton University Press.

Barthel-Bouchier, D., 2013. Cultural Heritage and the Challenge of Sustainability. Walnut Creek: Left Coast Press.

Berdahl, D., 2010. On the Social Life of Postsocialism. Bloomington and Indianapolis, Indiana: Indiana University Press.

Butrint Foundation, 2005. The Butrint Foundation Report for 2005. Accessed 12 July 2010 http://www.butrintfoundation.co.uk/Annual\%20Reports/ar05.pdf.

Butrint Foundation, 2006. The Butrint Foundation Report for 2006. Accessed 12 July 2010 http://www.butrintfoundation.co.uk/Annual\%20Reports/ar06.pdf.

Chirikure, S., M. Manyanga, W. Ndoro \& G. Pwiti, 2010. Unfulfilled promises? Heritage management and community participation at some of Africa's cultural heritage sites. International Journal of Heritage Studies 16: 30-44.

CISP, 2004. Context Analysis of Butrint National Park Surrounding Area. Saranda: CISP. Comer, D. C., 2012. Tourism and archaeological heritage management at Petra: driver to development or destruction? New York: Springer.

Coombe, R., \& M. BAird, 2016. The Limits of Heritage: Corporate Interests and Cultural Rights on Resource Frontiers, in: W. Logan, U. Kockel \& M. Craith (eds.), $A$ Companion to Heritage Studies. Wiley \& Sons Publishing, 337-354.

Delanty, G., 1995. Inventing Europe. London: MacMillan Press. 
Dimova, R., 2009. Neoliberalism, Nationalism, and Border Arrangement in the Southern Balkans. Working Paper.

Elyachar, J., 2005. Markets of Dispossession: NGOs, Economic Development, and the State in Cairo. North Carolina: Duke University Press.

Gould, P. G. \& P. Burtenshaw. 2014. Archaeology and economic development. Public Archaeology 13: 3-9.

Gow, D., 2002. Anthropology and Development: Evil Twin or Moral Narrative? Human Organization 61(4): 299-313.

Gupta, A., 2012. Red Tape Bureaucracy, Structural Violence, and Poverty in India. North Carolina: Duke University Press.

Hall, D. R., 1999. Albania: Representations of Place. The Geographical Journal 162(2): 161-172.

Hansen, P., 2000. "European Citizenship", or Where Neoliberalism Meets EthnoCulturalism. European Societies 2(2): 139-165.

Harrison, E., 2012. Performing Partnership: Inviting Participation and Older People's Forums. Human Organization 71(2): 157-166.

Harvey, D., 2007. A Brief History of Neoliberalism. Oxford: Oxford University Press.

Herrera, A., 2014. Commodifying the indigenous in the name of development: the hybridity of heritage in the twenty-first-century Andes. Public Archaeology 13: 71-84.

Kingfisher, C. \& J. Maskovsky. 2008. Introduction. The Limits of Neoliberalism. Critique of Anthropology 28(115): 115-126.

Kumi, E., A. Arhin \& T. Yeboah, 2014. Can Post-2015 Sustainable Development Goals Survive neoliberalism? A critical examination of the sustainable developmentneoliberalism nexus in developing countries. Environment, Development and Sustainability 16: 539-554.

Lafrenz SAmuels, K., 2010. Material heritage and poverty reduction, in: S. LABADi \& C. Long (eds.), Heritage and Globalisation. London and New York: Routledge, 202-217. Li, T., 2007. The Will to Improve: Governmentality, Development, and the Practice of Politics. North Carolina: Duke University Press.

Meskell, L., 2010. Human Rights and Heritage Ethics. Anthropological Quarterly 83(4): 839-859.

Mosse, D., 2004. Is Good Policy Unimplementable? Refelections of the Ethnography of Aid Policy and Practice. Development and Change 35(4): 639-671.

Pedersen, M., 2009. At Home Away from Homes: Navigating the Taiga in Northern Mongolia, in: P. Kirby (ed.), Boundless Worlds: An Anthropological Approach to Movement. New York and Oxford: Berghahn Books, 135-151.

Pettifer, J. \& M. Vickers. 2009. The Albanian Question: Reshaping the Balkans. London: I.B. Tauris.

Rajak, D., 2011a. In Good Company. An Anatomy of Corporate Social Responsibility. Stanford, California: Stanford University Press.

Rajak, D., 2011b. Theatres of Virtue: Collaboration, Consensus, and the Social Life of Corporate Responsibility. Journal of Global and Historical Anthropology 60: 9-20.

Rose, N., 2004. Powers of Freedom. Reframing Political Thought. Cambridge, United Kingdom: Cambridge University Press. 
SHore, C. \& M. AbÉLÈs, 2004. Debating the European Union: An Interview with Cris Shore and Marc Abélès. Anthropology Today 20(2): 10-14.

Sigona, N. \& N. Trehan, 2010. Romani Politics in Contemporary Europe: poverty, ethnic mobilization, and the neoliberal order. London: Pagrave MacMillan.

Silverman, H., 2011. Archaeologies of Engagement, Representation, and Identity. Historical Archaeology 45(1): 152-166.

UNESCO, 2004. Butrint. Accessed 5 Aug 2010 http://whc.unesco.org/en/list/570.

WeIss, L., 2014. Informal Settlements and Urban Heritage Landscapes in South Africa. Journal of Social Archaeology 14(1): 3-25.

WinTER, T., 2007. Post-conflict heritage, postcolonial tourism: tourism, politics and development at Angkor. London and New York: Routledge.

Winter, T., 2010. Heritage tourism: the dawn of a new era? in: S. LABADI \& C. LONG (eds.), Routledge Handbook of Heritage in Asia. London: Routledge, 117-129. 
